\title{
2010s-29 \\ The Porter Hypothesis at 20: Can Environmental Regulation Enhance Innovation and Competitiveness?
}

\author{
Stefan Ambec, Mark A. Cohen, Stewart Elgie, Paul Lanoie
}

\begin{tabular}{c}
\hline Série Scientifique \\
Scientific Series
\end{tabular}

\author{
Montréal \\ Août 2010
}

(C) 2010 Stefan Ambec, Mark A. Cohen, Stewart Elgie, Paul Lanoie. Tous droits réservés. All rights reserved. Reproduction partielle permise avec citation du document source, incluant la notice $\bigcirc$.

Short sections may be quoted without explicit permission, if full credit, including (C) notice, is given to the source.
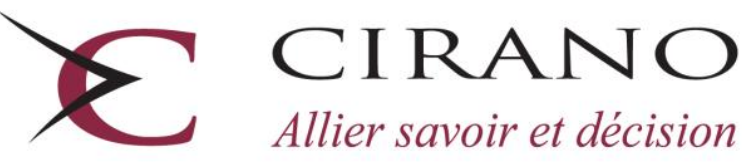

Allier savoir et décision

Centre interuniversitaire de recherche en analyse des organisations 


\section{CIRANO}

Le CIRANO est un organisme sans but lucratif constitué en vertu de la Loi des compagnies du Québec. Le financement de son infrastructure et de ses activités de recherche provient des cotisations de ses organisations-membres, d'une subvention d'infrastructure du Ministère du Développement économique et régional et de la Recherche, de même que des subventions et mandats obtenus par ses équipes de recherche.

CIRANO is a private non-profit organization incorporated under the Québec Companies Act. Its infrastructure and research activities are funded through fees paid by member organizations, an infrastructure grant from the Ministère du Développement économique et régional et de la Recherche, and grants and research mandates obtained by its research teams.

\section{Les partenaires du CIRANO}

Partenaire majeur

Ministère du Développement économique, de l'Innovation et de l'Exportation

\section{Partenaires corporatifs}

Banque de développement du Canada

Banque du Canada

Banque Laurentienne du Canada

Banque Nationale du Canada

Banque Royale du Canada

Banque Scotia

Bell Canada

BMO Groupe financier

Caisse de dépôt et placement du Québec

Fédération des caisses Desjardins du Québec

Gaz Métro

Hydro-Québec

Industrie Canada

Investissements PSP

Ministère des Finances du Québec

Power Corporation du Canada

Raymond Chabot Grant Thornton

Rio Tinto

State Street Global Advisors

Transat A.T.

Ville de Montréal

\section{Partenaires universitaires}

École Polytechnique de Montréal

HEC Montréal

McGill University

Université Concordia

Université de Montréal

Université de Sherbrooke

Université du Québec

Université du Québec à Montréal

Université Laval

Le CIRANO collabore avec de nombreux centres et chaires de recherche universitaires dont on peut consulter la liste sur son site web.

Les cahiers de la série scientifique (CS) visent à rendre accessibles des résultats de recherche effectuée au CIRANO afin de susciter échanges et commentaires. Ces cahiers sont écrits dans le style des publications scientifiques. Les idées et les opinions émises sont sous l'unique responsabilité des auteurs et ne représentent pas nécessairement les positions du CIRANO ou de ses partenaires.

This paper presents research carried out at CIRANO and aims at encouraging discussion and comment. The observations and viewpoints expressed are the sole responsibility of the authors. They do not necessarily represent positions of CIRANO or its partners. 


\title{
The Porter Hypothesis at 20: Can Environmental Regulation Enhance Innovation and Competitiveness?*
}

\author{
Stefan Ambec ${ }^{\dagger}$, Mark A. Cohen ${ }^{*}$, Stewart Elgie ${ }^{\S}$, Paul Lanoie ${ }^{* *}$
}

\begin{abstract}
Résumé
Il y a bientôt vingt ans, Michael Porter, économiste et professeur de stratégie de la Harvard Business School, a remis en question le paradigme généralement accepté quant à l'impact des réglementations environnementales sur la performance d'affaires, en affirmant que des politiques environnementales bien conçues pouvaient en fait améliorer la compétitivité des entreprises. Jusqu'alors, le point de vue dominant, accepté par la quasi-totalité des économistes, stipulait que d'imposer aux entreprises de réduire une externalité comme la pollution réduisait nécessairement les options à leur disposition et, par définition, leurs profits. Après tout, s'il y a des opportunités profitables de réduire la pollution, les firmes qui maximisent leurs profits auraient dû les identifier par elles-mêmes. Depuis 20 ans, beaucoup de choses ont été écrites sur ce qu'il est convenu d'appeler l'Hypothèse de Porter. Aujourd'hui, il y a diverses théories pour expliquer l'Hypothèse de Porter. Les résultats empiriques ne sont pas concluants et il subsiste une certaine confusion sur ce que dit et ne dit pas l'Hypothèse de Porter. Ce texte présente un survol des grands enjeux théoriques et empiriques entourant l'Hypothèse de Porter, en tire les grandes implications en termes de politiques publiques et propose des avenues de recherche pour le futur.
\end{abstract}

Mots clés : Hypothèse de Porter, politiques environnementales, innovation, performance.

\footnotetext{
Background paper for a symposium hosted by Sustainable Prosperity and Resources for the Future, on June 28, 2010.

The authors wish to thank Nick Johnstone, Leena Lankowski, David Popp, and Marcus Wagner for helpful comments on an earlier draft. All errors remain those of the authors.

${ }^{\dagger}$ Researcher, Toulouse School of Economics (NRA-LERNA) and Visiting Professor, University of Gothenburg (sambec@toulouse.inra.fr).

$\ddagger$ Vice President for Research and Senior Fellow, Resources for the Future; Professor of Management and Law, Vanderbilt University (cohen@rff.org).

${ }^{\S}$ Professor, Faculty of Law, University of Ottawa, Chair, Sustainable Prosperity; (stewart.elgie@ uottawa.ca)

*** Professor of Economics, HEC Montreal (paul_lanoie@ hec.ca).
} 


\begin{abstract}
Twenty years ago, Harvard Business School economist and strategy professor Michael Porter stood conventional wisdom about the impact of environmental regulation on business on its head by declaring that well designed regulation could actually enhance competitiveness. The traditional view of environmental regulation held by virtually all economists until that time was that requiring firms to reduce an externality like pollution necessarily restricted their options and thus by definition reduced their profits. After all, if there are profitable opportunities to reduce pollution, profit maximizing firms would already be taking advantage of those opportunities. Over the past 20 years, much has been written about what has since become known simply as the Porter Hypothesis ("PH"). Yet, even today, there is conflicting evidence, alternative theories that might explain the $P H$, and oftentimes a misunderstanding of what the PH does and does not say. This paper provides an overview of the key theoretical and empirical insights on the PH to date, draw policy implications from these insights, and sketches out major research themes going forward.
\end{abstract}

Keywords: Porter Hypothesis, environmental policy, innovation, performance. 


\section{INTRODUCTION}

Twenty years ago, Harvard Business School economist and strategy professor Michael Porter stood conventional wisdom about the impact of environmental regulation on business on its head by declaring that well designed regulation could actually enhance competitiveness. According to Porter (1991), "Strict environmental regulations do not inevitably hinder competitive advantage against foreign rivals; indeed, they often enhance it." He went on to suggest various mechanisms by which environmental regulations might enhance competitiveness; for example reduction in the use of costly chemicals or lower waste disposal costs. The traditional view of environmental regulation held by virtually all economists until that time was that requiring firms to reduce an externality like pollution necessarily restricted their options and thus by definition reduced their profits. After all, if there are profitable opportunities to reduce pollution, profit maximizing firms would already be taking advantage of those opportunities.

Over the past 20 years, much has been written about what has since become known simply as the Porter Hypothesis ("PH"). Yet, even today, there is conflicting evidence, alternative theories that might explain the $\mathrm{PH}$, and oftentimes a misunderstanding of what the $\mathrm{PH}$ does and does not say. However, a careful examination of both the theory and evidence yields some important policy implications for design of regulatory instruments - as well as a rich research agenda to further understand what works, what doesn't, and why.

This paper provides an overview of the key theoretical and empirical insights on the $\mathrm{PH}$ to date, and sketches out major research themes going forward. We start in Section 2 with a brief overview of the Porter Hypothesis - as well as the variations that have been expressed in the literature. Next, Section 3 examines the theoretical developments that have taken place over the past 20 years to explain why regulation might indeed improve competitiveness. Section 4 similarly reviews the empirical evidence to date. Section 5 enters the realm of policy recommendations, by examining the implications of our knowledge on the $\mathrm{PH}$ for designing regulatory mechanisms that promote innovation and competitiveness. Finally, we end with a section outlining what we see to be the main research gaps that have yet to be filled in this important policy area. 


\section{THE PORTER HYPOTHESIS}

The traditional view among economists and managers concerning environmental protection is that it comes at an additional cost imposed on firms, which may erode their global competitiveness. Environmental regulations ("ER") such as technological standards, environmental taxes or tradable emission permits force firms to allocate some inputs (labor, capital) to pollution reduction, which is unproductive from a business perspective. Technological standards restrict the choice of technologies or inputs in the production process. Taxes and tradable permits charge firms for their emission pollution, a by-product of the production process which was free before. These fees necessarily divert capital away from productive investments.

This traditional paradigm was challenged by a number of analysts, notably Professor Michael Porter (Porter, 1991) and his co-author Claas van der Linde (Porter \& van der Linde, 1995). Based on cases studies, the authors suggest that pollution is often a waste of resources and that a reduction in pollution may lead to an improvement in the productivity with which resources are used. More stringent but properly designed environmental regulations (in particular, market-based instrument such as taxes or cap-and-trade emission allowances) can "trigger innovation [broadly defined] that may partially or more than fully offset the costs of complying with them" in some instances (Porter \& van der Linde, 1995).

Figure 1 summarizes the main causal links involved in the PH. As Porter and van der Linde (1995) first described this relationship, if properly designed, environmental regulations can lead to "innovation offsets" that will not only improve environmental performance, but will partially - and sometimes more than fully - offset the additional cost of regulation.

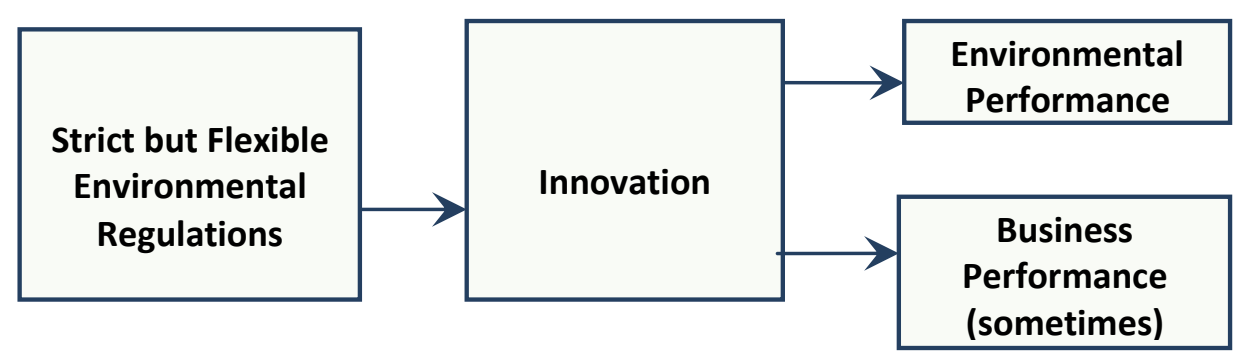

Figure 1. Schematic representation of the Porter Hypothesis

Porter and van der Linde go on to explain that there are at least five reasons that properly crafted regulations may lead to these outcomes:

- First, regulation signals companies about likely resource inefficiencies and potential technological improvements.

- Second, regulation focused on information gathering can achieve major benefits by raising corporate awareness.

- Third, regulation reduces the uncertainty that investments to address the environment will be valuable.

- Fourth, regulation creates pressure that motivates innovation and progress.

- Fifth, regulation levels the transitional playing field. 
Finally, they note "...we readily admit that innovation cannot always completely offset the cost of compliance, especially in the short term before learning can reduce the cost of innovation-based solutions."

The Porter hypothesis has met with great success in political debate, especially in the United States, because it refutes the idea that environmental protection is always detrimental to economic growth. It has been invoked to convince the business community to accept environmental regulations since they may benefit from them in addition to other stakeholders. In a nutshell, well-designed environmental regulations might lead to a Pareto improvement or "win-win" situation in some cases, by not only protecting the environment but also enhancing profits and competitiveness through the improvement of the production process or through enhancement of product quality.

The $\mathrm{PH}$ has been criticized for being incompatible with the assumption of profit-maximizing firms (see Palmer, Oates and Portney, 1995). Indeed, the hypothesis rests on the idea that firms often ignore profitable opportunities. In other words, why would regulation actually be needed for firms to adopt profit-increasing innovations? In fact, Porter directly questions the view that firms are profitmaximizing entities: "The possibility of regulation might act as a spur to innovation arises because the world does not fit the Panglossian belief that firms always make optimal choices." As discussed below, there are many reasons why firms might not appear to be making optimal choices - such as imperfect information, organizational or market failures.

Moreover, even if there are systematically-profitable business opportunities that are missed ("low hanging fruit"), the next question is how could environmental regulations change that reality? Are regulators in a better position than managers to find these profitable business opportunities? Porter argues that environmental regulation may help firms identify inefficient uses of costly resources. They may also produce and disseminate new information (e.g. best practice technologies) and help overcome organizational inertia.

There is much confusion in the literature about the Porter Hypothesis actually says. As we note above, it does not say that all regulation leads to innovation - only that well designed regulations do. This is consistent with the growing trend towards performance-based and/or market-based environmental regulations. Second, it does not state this innovation necessarily offsets the cost of regulation - i.e. it does not claim that regulation is always a free lunch. Instead, it does make the claim that in many instances, these innovations will more than offset the cost of regulation - i.e. there may be a free lunch in many cases.

Previous authors have disaggregated the $\mathrm{PH}$ into its component parts in order to test the theory and evidence. First, (as shown in the first two boxes of Figure 1), properly designed environmental regulation may spur innovation. This has often been called the "weak" version of the PH (see Jaffe and Palmer, 1997) because it does not tell us whether that innovation is good or bad for firms. Of course, the notion that regulation might spur technological innovation is not a new idea in economics, and would not itself have brought about such controversy. The second part of the PH (the lower right hand side of Figure 1) is that this innovation often more than offsets any additional regulatory costs - in other words, environmental regulation often leads to an increase in firm competitiveness. This is often called the "strong" version of the PH. (Note, however, that the PH never goes so far as to suggest that environmental regulation will always lead to either innovation or increased competitiveness.) Finally, in what has been called the "narrow" version of the PH, it is noted that flexible regulatory policies give firms greater incentives to innovate and thus are better than prescriptive forms of regulation. Indeed, Porter challenges regulators to examine the likely impacts of their actions and choose regulatory mechanisms that will foster innovation and competitiveness, particularly economic instruments. Thus, the $\mathrm{PH}$ is as much a normative prescription for regulatory policy as it is a positive assessment of current policy. 


\section{NEW DEVELOPMENTS IN THE THEORY}

This controversy gave rise to an abundant economics literature on the theoretical bases underlying the Porter hypothesis over the last 20 years. We can distinguish among two approaches. A first set of papers departs from the assumption of profit-maximizing firms in light of the emerging organizational and behavioural economic literature. The rationality of the firm is driven by its manager who has other motivations and objectives than profit maximization. He or she might be riskaverse (Kennedy, 1994), resistant to any costly change (Aghion, et al. 1997, Ambec and Barla, 2007) or rationally bounded (Gabel and Sinclair-Desgagné, 1998). He or she therefore misses good investment opportunities (from the point of view of the firm's profit) because they are too risky, too costly (for the manager but not for the firm) or out of the manager's habits and routines. In Ambec and Barla (2006), the manager has present-biased preferences that make her or him procrastinate profitable but costly investment opportunities ("low hanging fruit"). Since the cost of innovating is for "now" while the benefit is "later", a present-biased manager will tend to postpone any investments in innovation. By making those investments more profitable, or requiring them, environmental regulations help the manager overcome this self-control problem which enhances firm profits.

A related approach relies on an "organization failure" to reconcile the $\mathrm{PH}$ with a profit-maximizing firm. For example, Ambec and Barla (2002) cite two potential inefficiencies that support the PH: informational asymmetries inside the firm and a deficient governance structure. More precisely, managers may have private information about the outcome of an R\&D investment. Thus, in order to ensure productivity enhancement and less pollution from an R\&D investment, the manager will extract an informational rent (i.e. bonus). Instead, if the government imposes environmental regulations, managers lose their informational rent. The model is one way to formalize Porter's idea that environmental regulation may overcome organizational inertia.

A second set of papers reconcile the PH with profit maximization by assuming a 'market failure.' Under imperfect inter-firm competition, Simpson and Bradford (1996) show that a government may provide a strategic advantage to its domestic industry by imposing a more stringent environmental regulation. Also, with imperfect competition but differentiated products, André et al (2009) show that a minimum standard for environmental product quality might benefit all firms by solving a coordination problem - allowing them to reach a Pareto improving equilibrium. Mohr (2001) provides a similar coordination failure argument with technological spillovers. When the return on a firm's $R \& D$ investment is partly captured by its competitors, firms under-invest in cleaner and more productive technologies. An environmental regulation forcing adoption may thus switch the industry from an equilibrium with low investment in R\&D to a Pareto improving equilibrium with higher investments in R\&D. Greaker (2006) also relies on technological spillovers as a market failure to provide a theoretical foundation to the $\mathrm{PH}$ but with an upstream market for innovation. In the same vein, Xepapadeas and Zeeuw (1999) analyze the impact of environmental regulations on the dynamic of capital. They show that an emission tax may lead to retirement of older vintage capital, thereby increasing average productivity. ${ }^{1}$ However, despite this productivity gain, the impact on profit is negative in their study.

\footnotetext{
${ }^{1}$ Notice that Feichtinger et al. (2005) show that the opposite may occur: an emission tax may increase the capital's average age.
} 


\section{THE EMPIRICAL EVIDENCE}

Many researchers have attempted to test the Porter hypothesis empirically. Three approaches emerge from this empirical literature. The first intends to analyse the "weak" version of the $\mathrm{PH}$ - the link between the intensity of environmental regulation and innovation (that is to say the first link in the chain described in Figure 1). Operationally, innovation is generally assessed through R\&D expenses (input) or through the number of registered patents (the product of R\&D activity). However, as Porter and van der Linde (1995) make clear, innovation is not just technological change and can take various forms - including "a product's or service's design, the segments it serves, how it is produced, how it is marketed and how it is supported."

A summary of many of these studies is contained in an Appendix (adapted and updated from Ambec and Barla, 2006; Ambec and Lanoie, 2008). As an illustration of this first set of papers, Jaffe and Palmer (1997) estimate the relationship between total R\&D expenditures (or the number of successful patent applications) and pollution abatement costs (a proxy for the stringency of environmental regulation). They found a positive link with R\&D expenditures (an increase of $0.15 \%$ in R\&D expenditures for a pollution abatement cost increase of $1 \%$ ), but no statistically significant link with the number of patents. However, restricting themselves to environmentally-related successful patents, Brunnermeier and Cohen (2003), Popp (2003, 2006), Arimura (2007), and Lanoie et al. (2010) found a positive relationship with environmental regulation.

For the firm's technological choices, two older studies emphasize a negative relationship between environmental regulations and investment in capital. Nelson et al. (1993) found that air pollution regulations significantly increased the age of capital in the U.S. electric utilities in the seventies. As discussed later, however, this finding might not be surprising given the fact that U.S. regulations imposed more stringent requirements on new sources - likely an example of regulations that are not well designed to encourage innovation. According to Gray and Shabegian (1998), more stringent air and water regulations have a significant impact on paper mills' technological choice in the U.S. However, their results suggest that it tends to divert investment from productivity to abatement, consistently with the standard paradigm.

Altogether, these works deduce that there is a positive link, although varying in strength, between environmental regulation and innovation.

The second empirical approach assesses the impact of environmental regulation on the business performance of the firm (the link between the first and last steps in the chain described in Figure 1). The "strong" version of the Porter hypothesis is tested, however, without looking at the cause of this variation in performance (linked to innovation or to another cause). The firm's business performance is often measured by its productivity.

This second approach has a long tradition in the economic literature (see Jaffe et al., 1995, for a review). The second half of the Appendix lists many of these studies. Most papers reviewed in Jaffe et al. (1995) highlight a negative impact of environmental regulation on productivity. For instance, Gallop and Robert (1983) estimated that SO2 regulations slowed down productivity growth in the U.S. in the seventies by $43 \%$. However, several more recent papers (see Table 1 ) find more positive results. For example, Berman and Bui (2001) report that refineries located in the Los Angeles area enjoyed a significantly higher productivity than other U.S. refineries despite a more stringent air pollution regulation in this area. Similarly, Alpay et al. (2002) estimated the productivity of the Mexican food processing industry to be increasing with the pressure of environmental regulation. They therefore suggest that a more stringent regulation is not always detrimental to productivity. 
Lanoie et al. (2010) combines both approaches, assessing for the first time the whole Porter causality chain. The data come from a unique OECD survey carried out with more than 4,000 companies located in seven industrialized countries. The method consists of assessing three equations by proceeding in two stages with adequate instruments ("two-stage least squares"). Following Figure 1, the three dependent variables are environmental innovation, environmental performance and business performance. The results first show a positive and significant link between the perceived severity of environmental regulations and environmental innovation; this is consisitent with the weak version of the PH. Furthermore, the "predicted" environmental innovation from the first regression has a positive and significant impact on business performance. This provides evidence of the causal link suggested by the strong form of the $\mathrm{PH}$ - that regulation spurs innovation, which further enhances business performance. However, Lanoie et al. also note that environmental regulation has a direct negative effect on business performance. On balance, they find that the net effect is negative - that is, the positive effect of innovation on business performance does not outweigh the negative effect of the regulation itself. On balance, regulation appears to be costly - but less so than if one were to consider only the direct costs of regulation itself.

One important caveat to this negative finding is that most previous studies have not adequately taken into account the dynamic dimensions of the Porter Hypothesis. Porter argues that more stringent environmental policies will lead to innovations to reduce inefficiencies and this, in turn, will eventually reduce costs. This process may take some time. In previous studies on the determinants of productivity, researchers have often regressed productivity at time 0 on proxies of environmental regulation stringency at time 0 as well, which does not allow time for the innovation process to occur. By introducing lags of three or four years between changes in the severity of environmental regulations and their impact on productivity, Lanoie et al. (2008) have found that stricter regulations led to modest long-term gains in productivity in a sample of 17 Quebec manufacturing sectors - first reducing productivity in year one, a slightly positive effect in year two, and then more positive outcomes in years three and four - more than offsetting the first year's loss. Furthermore, they show that this effect is more important in industries highly exposed to outside competition. Further research should focus on these more dynamic impacts.

A third approach to evaluating the $\mathrm{PH}$ is to examine competition among nations - which returns to the original hypothesis of Porter that environmental regulation will enhance a country's competitiveness. Much of the empirical literature turns the issue on its head - examining the "pollution haven" hypothesis - that stringent environmental regulation will induce firms to leave the country for less strict (and hence, less expensive) regulatory regimes. The PH would suggest just the opposite. Of course, there are other reasons why firms might move polluting facilities abroad - such as differences in the cost of labour, land, transportation and other inputs (not just pollution).

Much of the earlier literature on the pollution haven hypothesis found a positive impact - industries with more stringent regulations (generally proxied by higher pollution abatement costs) had less net trade flows - consistent with the PH. However, as Copeland and Taylor (2004) and Brunnermeier and Levinson (2004) explain in their literature reviews, both endogeneity and unobserved variables that are correlated with regulation may explain these results. Indeed, they cite more recent literature accounting for these issues - and conclude that while much work still needs to be done, the weight of the evidence supports the pollution haven hypothesis. Nevertheless, the magnitude of this effect does not appear to be "strong enough to be the primary determinant of the direction of trade or investment flows." (Copeland and Taylor, 2004)." Perhaps more importantly from the perspective of the $\mathrm{PH}$, few of these studies have been able to distinguish between the type of regulatory mechanism employed - instead, they often use pollution control costs or emission levels (see e.g. Quiroga, Persson and Sterner, 2009) as proxies of regulatory stringency. While these might be reasonable measures of stringency, we do not know whether countries with more stringent policies are using "good" or "bad" forms of environmental regulation. 


\section{DESIGN OF POLICIES TO ENHANCE COMPETITIVENESS}

It is clear from both the original Porter writings and empirical evidence to date that both innovation and competitiveness outcomes depend significantly on the context. The PH itself was premised on flexible, market-based regulation - not rigid command and control regulation. Beyond environmental regulations, other government policies can interact with the link between environmental regulation and innovation or competitiveness. In this section, we briefly explore the implications of policy design for the $\mathrm{PH}$.

\section{Environmental Policies}

As mentioned by Porter, the type of regulatory instrument is an important premise of the PH. As Porter and van der Linde (1995) argue:

If environmental standards are to foster the innovation offsets that arise from new technologies and approaches to production, they should adhere to three principles. First, they must create the maximum opportunity for innovation, leaving the approach to innovation to industry and not the standard-setting agency. Second, regulations should foster continuous improvement, rather than locking in any particular technology. Third, the regulatory process should leave as little room as possible for uncertainty at every stage.

Market-based and flexible instruments such as emission taxes or tradable allowances, or performance standards, are more favourable to innovation than technological standard since they leave more freedom to firms on the technological solution to minimize compliance costs. Some authors, like Jaffe and Palmer (1997), refer to that as the narrow version of the PH. In this vein, Burtraw (2000) provides evidence that the switch in environmental regulations for $\mathrm{SO}_{2}$ emissions in the U.S. from a technological standard with emission caps to an allowance trading program in 1990 considerably reduced compliance cost ( $40 \%$ to $140 \%$ lower than projection) - although the net effect was still a net cost. However, the switch to an emission cap enhanced innovation and fostered organizational change and competition on the upstream input market. The program left enough flexibility for the firm to select the best strategy for reducing emissions, including a switch to coal with lower sulphur content. The industry also experienced innovation in fuel blending and in the scrubber market. ${ }^{2}$ In addition, the switch from a technological standard to tradable emission allowances led to a transfer of responsibility from engineers or chemists, typically in charge of environmental issues, to top executives such as financial vice-presidents, who are trained to treat $\mathrm{SO}_{2}$ emissions allowances as financial assets.

Along the same lines, Hoglund Isaksson (2005) looks at the impact of a charge on nitrogen oxides (NOx) emissions introduced in Sweden in 1992. She examines the impact on abatement cost functions of 114 combustion plants during the period 1990 - 1996. Her findings suggest that extensive emission reductions have taken place at zero or very low cost, and that effects of learning and technological development in abatement have been present during the analyzed period.

Lanoie et al. (2010) also provides indirect evidence on this issue, showing that performance standards are leading to more innovation than more prescriptive technological standards. Driessen (2005) reviews the literature and argues that environmental taxes provide a stronger incentive for innovation than do traditional regulations or emissions trading.

Finally, if market-based instruments generate revenues (e.g. from taxes or permit auctioning) then the efficient recycling of those revenues can improve competitiveness outcomes. For example,

\footnotetext{
${ }^{2}$ The former "command-and-control" did not provide incentives to increase $\mathrm{SO}_{2}$ removal by scrubbers from more than the $90 \%$ (for high-sulphur coal) or $70 \%$ (for low-sulphur coal) standard. With the new program, the incentives are such that upgrading of existing scrubbers through improvements is likely to occur.
} 
Andersen et al (2007) analyzed environmental tax revenues in seven EU countries that are recycled into other tax cuts (labour or income), and found that the result is a neutral or slightly positive net impact on GDP.

\section{Industrial and Patent Policies}

Industrial and patent policies might complement environmental regulation to protect the environment at lowest cost to firms. In particular, well-defined property rights on innovations might help to reduce R\&D spillovers to the benefit of all innovating firms while slowing diffusion. Mandatory licences might also foster technological adoption - but at the risk of reducing the incentive to invest in R\&D. Subsidies and tax credits for R\&D spending might make technological change as a strategy for environmental compliance more attractive. Popp (2006) provides evidence that the timing of the introduction of more stringent environmental regulations impact the number of patents issued on pollution abatement technology. This suggests that innovation policy is strongly related to environmental policy. Maskus (2010) contains a recent review of the literature and finds that the relationship between patent policy and innovation is complex - suggesting that there are no simple answers that fit all circumstances.

\section{Training}

Improved productivity or competitiveness under the $\mathrm{PH}$ relies heavily on the possibility of lowhanging fruit - although new technological innovations themselves are also important. Busy managers, especially in small-and-medium enterprises (SMEs), may not always have the time and the technical expertise to identify these profitable opportunities. Training may help them. RochonFabien and Lanoie (2010) investigate the benefits of an original Canadian training program, the Enviroclub initiative. This initiative was developed to assist SMEs in improving their profitability and competitiveness through enhanced environmental performance. An Enviroclub consists of a group of 10-15 SMEs, each of which carries out one profitable pollution prevention project. To support this practical experience, business participants attend 4 days of workshops on various themes related to environmental performance. They also receive the services of a consultant for 90 hours. This consultant analyzes the operations of the firm and, after a thorough diagnosis, recommends different measures to prevent pollution and enhance business performance. The participating firm is committed to adopt at least one of the recommendations of the consultant. Rochon-Fabien and Lanoie (2010) examine the first 187 projects emerging from this program and conclude that all of them were profitable for the participating firms, i.e. reducing costs and pollution at the same time. Lyon and van Hoof (2009) provide similar results for Mexico.

\section{Organizational or Governance Conditions}

As noted, Porter argued that organizational inertia can be one reason why firms are missing profitable opportunities to both reduce pollution and increase profits. In the same vein, environmental regulations might help firms to overcome their organizational inertia by forcing them to review the organization of production and their business model. This is more likely in firms with deficient governance structures, including asymmetric information with firms among divisions, lack of commitment by the hierarchy, costly communication, contractual incompleteness, etc. Such organizational or governance failures either constrain the ability of managers to pursue their objectives or distort incentives within the firm. The results from Burtraw (2000) showing how SO2 allowances were handled by financial officers instead of environmental managers is a good example - as financial officers presumably had more of an incentive to reduce pollution (which would either increase the value of allowance they could sell or reduce the need to buy allowances). Recent trends to increase corporate transparency and reporting (e.g. the Carbon Disclosure Project and Global Reporting Initiative), hire Corporate Responsibility Officers who oftentimes report directly to the Board of Directors, and to appoint members of the Board of Directors with sustainability experience - all point to actions that might reduce organizational inertia further. 


\section{THE FORWARD RESEARCH AGENDA}

After 20 years, the $\mathrm{PH}$ continues to stimulate academic research and policy debates. While we have learned a lot, findings are often very context specific. With changes in globalization, industry structure, and social expectations, the research agenda over the next 20 years is already full. We have categorized the future research agenda into four major themes:

\section{Data and Methodological Issues}

Much of the existing literature necessarily uses proxies for the key variables of interest. For example, in studies of innovation, environmental regulations are often proxied by environmental compliance costs. Yet, the PH does not posit that higher abatement costs will lead to innovation. Indeed, higher compliance costs might simply be attributable to older plants, for example, not more stringent regulatory standards. Instead, the PH suggests that more stringent environmental standards lead to investment in R\&D (or changes in processes, organizations, etc.), which in turn leads to innovation. The challenge for researchers is to find appropriate data to fully understand and test these mechanisms.

Another reason we might be observing conflicting results is that firm, industry or environmental characteristics affect the extent to which innovation offsets and productivity or competitiveness enhancements occur. What is it about manufacturing industries in Canada between 1985- 1994 (Lanoie et al., 2008) or the U.S. petroleum industry between 1987-1995 (Berman and Bui, 2001) that causes them to have an increase in productivity when faced with stricter environmental standards while just the opposite was found in U.S. pollution-intensive industries from U.S. paper mills between 1979-1990 (Gray and Shadbegian, 2003)?

These type challenges abound in the literature on the PH. Lankowski (2010) provides a nice summary of these issues and notes that authors have identified 50 or more methodological or measurement problems that make it difficult to compare and draw conclusions. Future research is not only needed to refine and improve upon these issues, but perhaps a serious meta-analysis would help uncover some of the underlying effects and shed more light on these issues.

\section{Non-regulatory Policies}

As noted above, there is some evidence that training programs may provide knowledge to environmental managers about more productive (and perhaps even profitable) approaches to environmental protection. Related to direct training on better compliance approaches, are the growing number of voluntary programs such as the 33/50 and Energy Star programs in the U.S. as well as elsewhere. While these programs are generally designed to provide companies with knowledge and/or incentives to go beyond compliance - either to reduce costs or to increase demand for their products - they may have significant ancillary benefits of increasing compliance with existing regulations.

In addition, there is growing evidence that mandatory disclosure programs have resulted in improvements in environmental performance - even when not mandated. For example, while Hamilton (1995) found that on average, firms lost market value on the day that the first TRI numbers were made public, Konar and Cohen (1997) found firms with the largest stock price declines subsequently reduced their emissions most. More importantly, Konar and Cohen (2001) found that subsequent reductions in TRI increased the intangible asset value of firms. These and other similar findings raise the interesting question of whether indirect forms of regulation such as mandatory disclosure yield positive or negative impacts on balance. 
Beyond the government, there are other actors whose policies might interact with the regulationinnovation-competitiveness links. As mentioned above, the trend towards increased transparency whether through voluntary corporate reporting, quasi-mandatory requirements from stock exchanges, etc., or third party reporting such as the Carbon Disclosure Project or www.scorecard.org, might reduce organizational inertia. This would appear a fruitful area for future research.

\section{Longitudinal Studies}

As noted, one reason we might continue to see mixed results on the regulation- competitiveness effect is the inability of previous studies to adequately capture the lag structure of innovation. While Brunnermeier and Cohen (2003) found a positive relationship between lagged compliance costs and innovation, and Lanoie et al. (2008) found a positive relationship between lagged regulatory stringency and productivity, most authors have relied upon contemporaneous comparisons. Innovations might take several years to develop - and capital expenditures are often delayed for a few years through normal budgetary cycles and building lags. Thus, future studies that carefully examine the dynamic structure of the $\mathrm{PH}$ would be welcome.

Lankoski (2010) suggested that this difference in treating lag structures was one reason why earlier studies are more likely to reject the $\mathrm{PH}$, while more recent studies appear more favourable. However, another potential reason that more recent studies are more likely to find positive results is simply that the world is changing over time. We have more experience with market-based regulation of the form advocated by Porter. Also, there is a heightened social consciousness around sustainability both green products and corporate social responsibility. Thus, the "value" of improving environmental performance may have increased over time. Capturing these effects in a longitudinal study might be difficult, but could provide some interesting insights.

\section{Global Studies}

As datasets become more global and we increase our ability to make cross-country comparisons with meaningful detailed data, more research might focus on the competitiveness across nations. As mentioned above, there is growing (but still not conclusive) evidence that countries with more stringent environmental regulations are less competitive in those sectors. However, future research might distinguish between command-and-control, performance-based and market-based instruments to whether the form of regulation has an impact on these findings. 


\section{REFERENCES}

Aghion P., M. Dewatripont et P. Rey (1997), "Corporate Governance, Competition Policy and Industrial Policy", European Economic Review, 41, 797-805.

Alpay, E., S. Buccola and J. Kerkvliet (2002), 'Productivity Growth and Environmental Regulation in Mexican and U.S. Food Manufacturing', American Journal of Agricultural Economics 84(4), 887-901.

André J. F., González P. and Portiero N. (2009), "Strategic Quality Competition and the Porter Hypothesis", Journal of Environmental Economics and Management, vol. 57, pp.182-194.

Ambec S. and P. Barla (2002), "A Theoretical Foundation of the Porter Hypothesis," Economics Letters, 75(3), 355-60.

Ambec, S. and P. Barla (2006), "Can Environmental Regulations Be Good for Business? An Assessment of the Porter Hypothesis," Energy Studies Review, 14(2), 42-62.

Ambec, S. and Barla P. (2007), "Quand la réglementation environnementale profite aux pollueurs. Survol des fondements théoriques de l'Hypothèse de Porter", L'Actualité économique, vol. $83, n^{\circ} 3$, pp. 399-414.

Ambec S. and Lanoie P. (2008). "Does it Pay to be Green? A Systematic Overview ", Academy of Management Perspectives, vol. 22, pp 45-62.

Andersen, M.S. et al. (2007), Competitiveness Effects of Environmental Tax Reforms (COMETR): Publishable Final Report to the European Commission, http://www2.dmu.dk/cometr/

Arimura, T., Hibiki, A., and N. Johnstone (2007), "An Empirical Study of Environmental R\&D: What Encourages Facilities to be Environmentally-Innovative?" in Johnstone, N. (Ed.) Corporate Behaviour and environmental Policy. Cheltenham, UK: Edward Elgar in association with OECD.

Barbera, A.J. and V.D. McConnell (1990), 'The Impact of Environmental Regulations on Industry Productivity: Direct and Indirect Effects', Journal of Environmental Economics and Management 18, 50-65.

Barla P., Constantatos C. and Herrmann M. (2008), "Environmental Regulation as a Coordination Device for Introduction of a Green Product: The Porter's Hypothesis Revisited", Document de travail, Université Laval, Québec, Canada.

Berman, E. and L.T.M. Bui (2001), 'Environmental Regulation and Productivity: Evidence from Oil Refineries' The Review of Economics and Statistics 83(3), 498-510.

Brunnermeier, S.B. and M.A. Cohen (2003), 'Determinants of Environmental Innovation in US Manufacturing Industries', Journal of Environmental Economics and Management 45, 278293.

Brunnermeier, S.G. and A. Levinson (2004), "Examining the Evidence on Environmental Regulations and Industry Location." Journal of Environment \& Development, 13(6), 6-41.

Burtraw, D. (2000), "Innovation Under the Tradable Sulfur Dioxide Emission Permits Program in the U.S. Electricity Sector", Discussion Paper 00-38, Resources For the Future (RFF), Washington. 
Copeland, B.R. and M.S. Taylor (2004), "Trade, Growth and the Environment." Journal of Economic Literature, 42, 7-71.

Driesen, D. "Economic Instruments for Sustainable Development," Chapter 9 in Environmental Law for Sustainability: A Critical Reader (S. Wood, B. Richardson eds., Hart Publications 2005), http://law.syr.edu/Pdfs/Oosgoodehallboo.pdf .

Dufour, C., P. Lanoie and M. Patry (1998), 'Regulation and Productivity', Journal of Productivity Analysis 9, 233-247.

Esty, Daniel C. and Michael E. Porter (1998), "Industrial Ecology and Competitiveness: Strategic Implications for the Firm", Journal of Industrial Ecology, 2(1), 35-44.

Esty, Daniel C. and Michael E. Porter (2002), "Ranking National Environmental Regulation and Performance: A Leading Indicator of Future Competitiveness?" in The Global Competitiveness Report 2001-2002 (Michael E. Porter, Jeffrey Sachs et al). New York: Oxford University Press, 78-100.

Esty, Daniel C. and Michael E. Porter (2005), "National Environmental Performance: An Empirical Analysis of Policy Results and Determinants", Environment and Development Economics, 10(4).

Fare R., S. Grosskopf, C.A.K. Lovell and C. Pasurka (1989), 'Multilateral Productivity Comparison when Some Outputs are Undesirable: a Nonparametric Approach', The Review of Economics and Statistics, 71, p. 90-98.

Feichtinger, G., R.F. Hartl, P.M. Kort and V.M. Veliov (2005) 'Environmental Policy, the Porter Hypothesis and the Composition of Capital: Effects of Learning and Technological Progress' Journal of Environmental Economics and Management, 50(2), 434-446.

Gabel, H.L. and B. Sinclair-Desgagné (1998) 'The Firm, its Routines, and the Environment', in The International Yearbook of Environmental and Resource Economics 1998/1999: A Survey of Current Issues, editors: H. Folmer and T. Tietenberg, Edward Elgar.

Gollop, F.M. and M.J. Roberts (1983), 'Environmental Regulations and Productivity Growth: The Case of Fossil-fuelled Electric Power Generation', Journal of Political Economy 91(4), 654-674.

Gray, W.B., (1987), 'The Cost of Regulation: OSHA, EPA and the Productivity Slowdown', The American Economic Review 77(5), 998-1006.

Gray, W.B. and R.J. Shadbegian (1998), 'Environmental Regulation Investment Timing, and Technology Choice', The Journal of Industrial Economics XLVI(2), 235-256.

Gray, W.B. and R.J. Shadbegian (2003), 'Plant Vintage, Technology, and Environmental Regulation', Journal of Environmental Economics and Management 46, 384-402.

Greaker, M. (2003), "Strategic Environmental Policy; Eco-dumping or a Green Strategy?" Journal of Environmental Economics and Management, 45(3), 692-707.

Hamilton, J.T. (1995), "Pollution as News: Media and Stock Market Reactions to the Toxics Releaase Inventory Data," Journal of Environmental Economics and Management 28, 98-113. 
Hoglund Isaksson, L. (2005), "Abatement Costs in Response to the Swedish Charge on Nitrogen Oxide Emissions" Journal of Environmental Economics and Management 50, 102-120.

Jaffe, A.B. and K. Palmer (1997), "Environmental Regulation and Innovation: A Panel Data Study", The Review of Economics and Statistics 79(4), 610-619.

Kennedy, Peter (1994), "Innovation stochastique et coût de la réglementation environnementale", L'Actualité économique 70(2): 199-209.

Konar, S., and M. A. Cohen (1997), "Information As Regulation: The Effect of Community Right to Know Laws on Toxic Emissions," Journal of Environmental Economics and Management 32, 109-24.

Konar, S., and M. A. Cohen (2001), "Does the Market Value Environmental Performance?" Review of Economics and Statistics 83(2), 281-89.

Lankoski, L. (2010), "Linkages between Environmental Policy and Competitiveness", OECD Environment Working Papers, No. 13, http://www.oecd.org/dataoecd/0/8/44392874.pdf.

Lanoie, P., J. Lucchetti, N. Johnstone, and S. Ambec (2010), "Environmental Policy, Innovation and Performance: New Insights on the Porter Hypothesis", forthcoming in Journal of Economics and Management Strategy.

Lanoie, P., Patry, M., Lajeunesse, R. (2008), "Environmental Regulation and Productivity: New Findings on the Porter Hypothesis", Journal of Productivity Analysis 30: 121-128.

Lyon, T.; Van Hoof, B. (2009) Evaluating Mexico Green Supply Chains Program, mimeo, University of Michigan (August).

Maskus, K. (2010), "Differentiated Intellectual Property Regimes for Environmental and Climate Technologies," OECD Environment Working Papers, No. 17, OECD Publishing. www.oecd.org/dataoecd/38/11/45198038.pdf.

Mohr R.-D. (2002), "Technical Change, External Economies, and the Porter Hypothesis," Journal of Environmental Economics and Management, 43(1), 158-68.

Nelson R.A., T. Tietenberg and M.R. Donihue (1993), 'Differential Environmental Regulation: Effects on Electric Utility Capital Turnover and Emissions' The Review of Economics and Statistics 75(2), 368-373

Palmer, K., W.E. Oates and P.R. Portney (1995), "Tightening Environmental Standards: The BenefitCost or the No-Cost Paradigm?" Journal of Economic Perspectives, 9(4), 119-32.

Popp, D. (2003), "Pollution Control Innovations and the Clean Air Act of 1990", Journal of Policy Analysis and Management, 22(4), 641-660.

Popp, D. (2006), "International Innovation and Diffusion of Air Pollution Control Technologies: The Effects of NOX and SO2 Regulation in the US, Japan, and Germany", Journal of Environmental Economics and Management, 51(1), 46-71.

Porter, M. (1991), “America's Green Strategy,” Scientific American, 264(4), 168. 
Porter, M. and C. van der Linde (1995), "Toward a New Conception of the EnvironmentCompetitiveness Relationship," Journal of Economic Perspective, 9(4), 97-118.

Quiroga, M., M. Persson and T. Sterner (2009), “Do Countries with Lax Environmental Regulations Have a Comparative Advantage in Polluting Industries?" Working Paper.

Rassier, D.G., Earnhart, D. (2010) "The Effect of Clean Water regulation on Profitability: Testing the Porter Hypothesis" Land Economics 86 (2): 329-344.

Repetto, Roberts, Dale Rothman, Paul Faeth et Duncan Austin (1996), Has Environmental Protection Really Reduced Productivity Growth?, World Resources Institute.

Rochon-Fabien, A., Lanoie, P. (2010) "Promoting Pollution Prevention in Small Businesses: Costs and Benefits of the "Enviroclub" Initiative", Mimeo, HEC Montreal.

Simpson D. and R.L. Bradford (1996), "Taxing Variable Cost: Environmental Regulation as Industrial Policy," Journal of Environmental Economics and Management, 30(3), 282-300.

Smith J.B. and W.A. Sims (1985), 'The Impact of Pollution Charges on Productivity Growth in Canadian Brewing', The Rand Journal of Economics 16(3), 410-423.

Xepapadeas, A. and A. de Zeeuw (1999) 'Environmental Policy and Competitiveness: The Porter Hypothesis and the Composition of Capital', Journal of Environmental Economics and Management 37, 165-182. 


\section{APPENDIX}

\section{EMPIRICAL STUDIES ON THE PORTER HYPOTHESIS}

\begin{tabular}{|c|c|c|c|}
\hline STUDY & DATA & METHODOLOGY & MAIN RESULTS \\
\hline \multicolumn{4}{|c|}{ I. Impact of Environmental Regulations (ERs) on Innovation and Technology } \\
\hline $\begin{array}{l}\text { Jaffe and } \\
\text { Palmer (1997) }\end{array}$ & $\begin{array}{l}\text { Panel of U.S. } \\
\text { manufacturing } \\
\text { industries - } \\
\text { 1973-1991. }\end{array}$ & $\begin{array}{l}\text { - Reduced form model. } \\
\text { - Innovation proxy: R\&D } \\
\text { investments and number of } \\
\text { successful patent } \\
\text { applications. } \\
\text { - ERs proxy: Pollution control } \\
\text { capital costs. }\end{array}$ & $\begin{array}{l}\text { R\&D significantly } \\
\text { increases with ERs. } \\
\text { Elasticity: }+0.15 \text {. } \\
\text { - No significant impact of } \\
\text { ERs on number of patents. }\end{array}$ \\
\hline $\begin{array}{l}\text { Brunnermeier } \\
\text { and Cohen } \\
(2003)\end{array}$ & $\begin{array}{l}\text { - Panel of } 146 \\
\text { U.S. } \\
\text { manufacturing } \\
\text { industries 1983- } \\
1992 .\end{array}$ & $\begin{array}{l}\text { - Reduced form model. } \\
\text { - Innovation proxy: number of } \\
\text { environmentally-related } \\
\text { successful patent } \\
\text { applications. } \\
\text { - ERs: Pollution control } \\
\text { operating costs and number } \\
\text { of air and water pollution } \\
\text { control inspections. }\end{array}$ & $\begin{array}{l}\text { - Small but significant } \\
\text { impact of pollution } \\
\text { operating cost on number } \\
\text { of patents. } \\
\text { - No impact of inspections. }\end{array}$ \\
\hline $\begin{array}{l}\text { Nelson et al. } \\
\text { (1993) }\end{array}$ & $\begin{array}{l}\text { 44 U.S. electric } \\
\text { utilities over the } \\
\text { 1969-1983 } \\
\text { period. }\end{array}$ & $\begin{array}{l}\text { - Three-equation model: i) age } \\
\text { of capital; ii) emissions; and } \\
\text { iii) regulatory expenditures. } \\
\text { - Model includes two ER } \\
\text { proxies: air pollution cost and } \\
\text { total pollution control costs } \\
\text { per KW capacity. }\end{array}$ & $\begin{array}{l}\text { - ERs significantly increase } \\
\text { age of capital (elasticity: } \\
\text { +0.15). } \\
\text { - Age of capital has no } \\
\text { statistically-significant } \\
\text { impact on emissions. } \\
\text { - Regulation has impacted } \\
\text { emission levels. }\end{array}$ \\
\hline $\begin{array}{l}\text { Arimura et al. } \\
\text { (2007) }\end{array}$ & $\begin{array}{l}\text { - Survey of } 4000 \\
\text { manufacturing } \\
\text { facilities in } \\
\text { seven OECD } \\
\text { countries. }\end{array}$ & $\begin{array}{l}\text { - Bivariate probit model with } \\
\text { (1) Environmental R\&D } \\
\text { dummy regressed on various } \\
\text { measures of environmental } \\
\text { policy (perceived stringency, } \\
\text { standards, taxes), an } \\
\text { environmental accounting } \\
\text { dummy and other } \\
\text { management practices } \\
\text { control variables. } \\
\text { (2) Environmental accounting } \\
\text { dummy regressed on same } \\
\text { variables. }\end{array}$ & $\begin{array}{l}\text { - The perceived ER } \\
\text { stringency has a positive } \\
\text { and significant impact on } \\
\text { the probability to a run an } \\
\text { environmental R\&D } \\
\text { program. } \\
\text { - The type of ER (standard } \\
\text { or tax) has no significant } \\
\text { effects on environmental } \\
\text { R\&D. }\end{array}$ \\
\hline Popp (2003) & $\begin{array}{l}\text { - Patent data and } \\
\text { performance } \\
\text { measures of } \\
\text { flue gas desul- } \\
\text { furization units } \\
\text { (“scrubbers") of } \\
186 \text { plants in US } \\
\text { (1972-97). }\end{array}$ & $\begin{array}{l}\text { - SO2 removal efficiency of } \\
\text { new scrubbers regressed on } \\
\text { the flow of knowledge } \\
\text { (measured by patents) and } \\
\text { policy variables. } \\
\text { - Operating and maintenance } \\
\text { cost of scrubbers regressed } \\
\text { on same variables. }\end{array}$ & $\begin{array}{l}\text { The new SO2 emission } \\
\text { permit regulation } \\
\text { introduced in } 1990 \\
\text { increased SO2 removal } \\
\text { efficiency and lowered } \\
\text { operating and removal } \\
\text { costs. }\end{array}$ \\
\hline Popp (2006) & - Patent data & - Impact of $\mathrm{SO}_{2}$ (US) and $\mathrm{NO}_{\mathrm{x}}$ & - ERs followed by an \\
\hline
\end{tabular}




\begin{tabular}{|c|c|c|c|}
\hline & $\begin{array}{l}\text { from the U.S., } \\
\text { Japan, and } \\
\text { Germany (1967- } \\
\text { 2001). }\end{array}$ & $\begin{array}{l}\text { (Germany and Japan) ERs on } \\
\text { patenting and patent } \\
\text { citations. } \\
\text { - ERs: timing of the } \\
\text { introduction of new ERs. } \\
\text { - Estimate the cross-countries } \\
\text { spillovers using patent } \\
\text { citation origins. }\end{array}$ & $\begin{array}{l}\text { increase of patenting from } \\
\text { domestic firms but not } \\
\text { from foreign firms. } \\
\text { - Earlier ERs for } \mathrm{NO}_{\mathrm{x}} \text { in } \\
\text { Germany and Japan are } \\
\text { important components of } \\
\text { US patents for pollution } \\
\text { control technologies to } \\
\text { reduce } \mathrm{NO}_{\mathrm{x}} \text { emissions. }\end{array}$ \\
\hline \multicolumn{4}{|c|}{ II. Impact of ERs on Productivity } \\
\hline $\begin{array}{l}\text { Gollop and } \\
\text { Robert (1983) }\end{array}$ & $\begin{array}{l}\text { - } 56 \text { U.S. electric } \\
\text { utilities, 1973- } \\
1979 .\end{array}$ & $\begin{array}{l}\text { - Productivity measure: derived } \\
\text { from the estimation of a cost } \\
\text { function that includes the ERs } \\
\text { proxy. } \\
\text { - ERs: the intensity of } \mathrm{SO}_{2} \\
\text { regulations based on actual } \\
\text { emissions, state standard and } \\
\text { the utility estimated } \\
\text { unconstrained emission } \\
\text { levels. }\end{array}$ & $\begin{array}{l}\text { - ERs reduce productivity } \\
\text { growth by } 43 \% \text {. }\end{array}$ \\
\hline $\begin{array}{l}\text { Smith and } \\
\text { Sims (1983) }\end{array}$ & $\begin{array}{l}\text { - } 4 \text { Canadian beer } \\
\text { breweries, } \\
\text { 1971-1980. }\end{array}$ & $\begin{array}{l}\text { - Productivity measure: derived } \\
\text { from the estimation of a cost } \\
\text { function. } \\
\text { - Two breweries were } \\
\text { submitted to an effluent } \\
\text { surcharge and two breweries } \\
\text { were not. }\end{array}$ & $\begin{array}{l}\text { Average productivity } \\
\text { growth regulated } \\
\text { breweries }-0.08 \% \\
\text { compared to }+1.6 \% \text { for } \\
\text { the unregulated plants. }\end{array}$ \\
\hline Gray (1987) & $\begin{array}{l}450 \text { U.S. } \\
\text { manufacturing } \\
\text { industries, } \\
1958-1978 .\end{array}$ & $\begin{array}{l}\text { - Change in average annual } \\
\text { total factor productivity } \\
\text { growth between } 1959-69 \\
\text { period and the } 1973-78 \\
\text { period regresses on pollution } \\
\text { control operating costs. }\end{array}$ & $\begin{array}{l}30 \% \text { of the decline in } \\
\text { productivity growth in the } \\
\text { seventies due to ERs. }\end{array}$ \\
\hline $\begin{array}{l}\text { Barbera and } \\
\text { Mc Connel } \\
\text { (1990) }\end{array}$ & $\begin{array}{l}\text { - } 5 \text { U.S. pollution } \\
\text { intensive } \\
\text { industries } \\
\text { (paper, } \\
\text { chemical, stone- } \\
\text { clay-glass, iron- } \\
\text { steel, non- } \\
\text { ferrous metals), } \\
\text { 1960-1980. } \\
\end{array}$ & $\begin{array}{l}\text { Derive the direct (abatement } \\
\text { cost growth) and indirect } \\
\text { (changes in other inputs and } \\
\text { production process) effects of } \\
\text { pollution control capital using } \\
\text { a cost function approach. }\end{array}$ & $\begin{array}{l}\text { - Overall, abatement capital } \\
\text { requirements reduce } \\
\text { productivity growth by } \\
10 \% \text { to } 30 \% \text {. } \\
\text { - Indirect effect sometimes } \\
\text { positive. }\end{array}$ \\
\hline $\begin{array}{l}\text { Dufour, } \\
\text { Lanoie and } \\
\text { Patry (1998) }\end{array}$ & $\begin{array}{l}19 \text { Quebec } \\
\text { manufacturing } \\
\text { industries, } \\
\text { 1985-1988. }\end{array}$ & $\begin{array}{l}\text { - Total factor productivity } \\
\text { growth regressed on changes } \\
\text { in the ratio of the value of } \\
\text { investment in pollution- } \\
\text { control equipment to total } \\
\text { cost. }\end{array}$ & $\begin{array}{l}\text { ERs have a significantly } \\
\text { negative impact on } \\
\text { productivity growth rate. }\end{array}$ \\
\hline $\begin{array}{l}\text { Berman and } \\
\text { Bui (2001) }\end{array}$ & $\begin{array}{l}\text { - US petroleum } \\
\text { refining } \\
\text { industry, 1987- } \\
1995 . \\
\end{array}$ & $\begin{array}{l}\text { - Comparison of total factor } \\
\text { productivity of California } \\
\text { South Coast refineries } \\
\text { (submitted to stricter air }\end{array}$ & $\begin{array}{l}\text { - Stricter regulations imply } \\
\text { higher abatement costs. } \\
\text { However, these } \\
\text { investments appear to }\end{array}$ \\
\hline
\end{tabular}




\begin{tabular}{|c|c|c|c|}
\hline & & $\begin{array}{l}\text { pollution regulations) with } \\
\text { other US refineries. } \\
\text { - ERs severity is measured by } \\
\text { the number of environmental } \\
\text { regulations each refinery is } \\
\text { submitted to. }\end{array}$ & increase productivity. \\
\hline $\begin{array}{l}\text { Lanoie, } \\
\text { Lajeunesse } \\
\text { and Patry } \\
(2008)\end{array}$ & $\begin{array}{l}\text { - } 17 \text { Quebec } \\
\text { manufacturing } \\
\text { industries, } \\
\text { 1985-1994. }\end{array}$ & $\begin{array}{l}\text { - Total factor productivity } \\
\text { growth regressed on lagged } \\
\text { changes in the ratio of the } \\
\text { value of investment in } \\
\text { pollution-control equipment } \\
\text { to total cost. }\end{array}$ & $\begin{array}{l}\text { ERs have a significantly } \\
\text { positive impact on } \\
\text { productivity growth rate, } \\
\text { using lagged results, } \\
\text { especially in the sectors } \\
\text { highly exposed to outside } \\
\text { competition. }\end{array}$ \\
\hline $\begin{array}{l}\text { Alpay, } \\
\text { Buccola and } \\
\text { Kerkvliet } \\
\text { (2002) }\end{array}$ & $\begin{array}{l}\text { - Mexican and } \\
\text { U.S. processed } \\
\text { food sectors } \\
\text { (1962-1994). }\end{array}$ & $\begin{array}{l}\text { - Productivity measure } \\
\text { obtained through the } \\
\text { estimation of a profit function } \\
\text { that includes pollution } \\
\text { abatement expenditures (US) } \\
\text { and inspection frequency } \\
\text { (Mexico) as proxies for ERs. }\end{array}$ & $\begin{array}{l}\text { - US: negligible effect of ERS } \\
\text { on both profit and } \\
\text { productivity. } \\
\text { - Mexico: ERs have a } \\
\text { negative impact on profits } \\
\text { but a positive impact on } \\
\text { productivity. }\end{array}$ \\
\hline $\begin{array}{l}\text { Gray and } \\
\text { Shadbegian } \\
\text { (2003) }\end{array}$ & $\begin{array}{l}\text { - } 116 \text { U.S. paper } \\
\text { mills, 1979- } \\
1990 .\end{array}$ & $\begin{array}{l}\text { - Regression of total factor } \\
\text { productivity on pollution } \\
\text { abatement operating costs, } \\
\text { technology and vintage } \\
\text { dummies and interaction } \\
\text { terms between the dummies } \\
\text { and the abatement variable. } \\
\text { - Estimation of a production } \\
\text { function that includes beside } \\
\text { input prices, pollution } \\
\text { abatement costs and other } \\
\text { control variables. }\end{array}$ & $\begin{array}{l}\text { - Significant reduction in } \\
\text { productivity associated } \\
\text { with abatement efforts } \\
\text { particularly in integrated } \\
\text { paper mills. }\end{array}$ \\
\hline $\begin{array}{l}\text { Rassier and } \\
\text { Earnhart } \\
\text { (2010) }\end{array}$ & $\begin{array}{l}73 \text { US chemical } \\
\text { firms, 1995- } \\
2001\end{array}$ & $\begin{array}{l}\text { Regression of Returns on sales } \\
\text { on permitted wastewater } \\
\text { discharge limits }\end{array}$ & $\begin{array}{l}\text { Tighter regulations } \\
\text { meaningfully lowers } \\
\text { profitability }\end{array}$ \\
\hline $\begin{array}{l}\text { Lanoie et al. } \\
\text { (2007) }\end{array}$ & $\begin{array}{l}4200 \\
\text { manufacturing } \\
\text { facilities in } 7 \\
\text { OECD countries, } \\
2003\end{array}$ & $\begin{array}{l}\text { - Mail survey } \\
\text { - Three equations estimated } \\
\text { with dependent variables: (1) } \\
\text { presence of Environmental } \\
\text { R\&D, (2) Environmental } \\
\text { performance, (3) Business } \\
\text { performance. Key independent } \\
\text { variables include perceived } \\
\text { regulatory stringency and policy } \\
\text { mechanisms. }\end{array}$ & $\begin{array}{l}\text { Tighter ER increases R\&D } \\
\text { which improves business } \\
\text { performance. However, } \\
\text { direct effect of ER is } \\
\text { negative; combined } \\
\text { impact is negative } \\
\text { (innovation offsets do not } \\
\text { offset cost of ER). }\end{array}$ \\
\hline
\end{tabular}

